\title{
Temptation and the virtues of long-term commitment: the governance of sovereign wealth fund investment
}

Gordon L Clark School of Geography and the Environment, Oxford University Centre for the Environment, South Parks Rd., Oxford OX2 7AZ, United Kingdom

Contact.gordon.clark@ouce.ox.ac.uk

\begin{abstract}
Debate over the significance of sovereign wealth funds tends to emphasize the geopolitical consequences of their investments. By contrast, in this paper we look at the governance of sovereign wealth funds from the perspective of the competing political interests embedded in the sponsor-the domestic political claims on funds and the principles and practice of governance used to discipline those interests in favour of a long-term perspective that emphasizes the conservation of wealth and the intergenerational transfer of benefits. It is noted that there is an ever-present temptation that faces the nation-state sponsors of sovereign wealth funds: the option of spending the assets for current political advantage and legitimacy. These issues are explored through a case study of the Australian government's design of their Future Fund. The government faced squarely the question of political temptation and in response instituted a model of governance that could be thought to have 'tamed' politics. The paper focuses on the principles used to design the Future Fund and references recent research on best practice investment management. Whereas the Future Fund is thought by many to be just another pension fund in the guise of a sovereign institution it is shown that it has certain important characteristics that distinguish it from a conventional pension fund. The implications of an expanded definition of intergenerational equity are drawn for the notion of long-term investment.
\end{abstract}

Keywords. Governance, long-term investment decision-making, politics, temptation

JEL Codes. F33, F59, G23

Acknowledgements. This paper was supported by a grant from the Leverhulme Trust for the study of sovereign wealth funds (with Ashby Monk). It draws upon work on the governance of financial institutions, and in particular pension funds, with a number of organisations and individuals notably Roger Urwin from Watson Wyatt. The paper bears the imprint of a series of interviews about the design and structure of the Australian superannuation industry and the Future Fund. I am especially grateful for the time and patience of Paul Costello, the Hon. Peter Costello, and Senator Nick Sherry. I should also acknowledge the assistance of Claire Woods in two of the interviews conducted in Melbourne over December 2008. Thanks are also due to Nicholas Howarth, Eric Knight, Phil O’Neill, Claire Woods and Ashby Monk for comments on a previous draft. None of the above should be held responsible for any errors or omissions or interpretations contained herein. 


\section{Introduction}

Debate over the significance of sovereign wealth funds (SWFs) has focused, in part, on the geopolitics of investment: the extent to which SWFs are the instruments of their sponsoring nation-states with certain geopolitical goals and objectives. That these interests are expressed, or may be expressed, through investment given the financial crisis facing many western advanced economies is cause enough to give life to political anxieties in the target or destination states. When coupled with nations' strategic interests in maintaining the control of nominally 'private' infrastructure and commercial assets, it is little wonder that the governance of (distant) sovereign funds has become such a contentious issue. As Monk (2008) suggested, at issue is the legitimacy of these funds not withstanding claims that they should be treated as any other investment fund as regards their search for superior risk-adjusted rates of return.

Academic interest in the topic spans the social sciences from politics and international relations through to economics, geography and political economy. At the same time, there is increasing recognition that the 'threat' posed by SWFs to western democracies may have been overplayed given the collapse in global commodity prices: with Brent Crude trading around $\$ 40-50$ per barrel and with other resource prices following oil prices albeit at significant time lag, Russia (for example) may well be facing a financial crisis that will be deeper and more far-reaching in terms of its domestic political significance than the global economic crisis facing western states. There is, as a consequence, an increasing premium on the use of SWF assets for domestic purposes- the assets of SWFs may well be the means by which some countries survive the global credit crisis albeit at the cost of realising long-term investment goals and objectives. ${ }^{1}$

In this paper, we look at the design and governance of the AUS\$70 billion Australian Future Fund (FF) arguing that it is representative of two interrelated commitments made by its political sponsors. At one level, its long-term mandate is framed by a commitment to intergenerational equity simultaneously managing competing claims for the spending of government revenue while conceptualizing what is meant by the

\footnotetext{
\%. It is arguable that one lesson learnt by Asian political leaders from the 1997 financial crisis was that the only way to avoid being held to account by the International Monetary Fund (IMF) in the future was to accumulate foreign currency reserves sufficient to 'cover' national obligations in the case of another financial meltdown.
} 
long-term. It is argued that this 'frame' set the terms for understanding the purpose of the fund in so doing taking advantage of political support for the policy while effectively neutralising opposition within and without the governing coalition. ${ }^{2}$ At another level, the government made a commitment to international best practice in the governance of the institution thereby leading other similar institutions around the world and reinforcing its commitment to the over-riding purpose of the fund. These moves are argued to have been strategic in that they represent choices made with respect to competing political claims but are underpinned by a principled-approach to the inevitable claims and counter-claims for short-term political advantage.

By this account, the fund's strong Petersen Institute score on transparency is owed less to a concern that it be accorded international respect for its independence and professionalism and more to a realisation by its founding political sponsors that, if successful, the fund could become a target for domestic political opportunism as regards its 'proper' investment goals and objectives. The Future Fund is distinctive on a number of counts. While its initial funding was derived from burgeoning global commodity prices, its assets were separated from government accounts and givenover to the FF management company before the global financial downturn exacted any claim on the budgetary position of the federal government. As well, the FF was conceived to be a long-term investor-unlike some funds that are silent or ambivalent about their time horizons, the enabling legislation set 2020 and 2040 as reference points for realising its goals and objectives.

There is an accepted political principle that provides the FF with its long-term mandate even if that principle can be contested. We also show that the formal constitution of the fund reflects a series of choices made about the responsibility and accountability of board members that went beyond conventional expectations derived from trust law and pension plan governance. Recognising that no parliament can tie the hands of future parliaments, the status and significance accorded to board members suggests that they represent a claim by future generations on current public policy-the sponsors of the FF hope that board members will act as a more effective

2 . The significance of 'framing' for negotiation and subsequent agreement is developed by Sebenius (1996) in his account of how coalitions are built to achieve certain outcomes by those that have the power to set the initial terms of debate. The issue of framing is also associated with decision-making under risk and uncertainty; for the seminal treatment see Kahneman and Tversky (1979). 
bulwark against short-term expediency than is true for pension fund trustees (Clark 2009; Shiller 2002). These arguments are illustrated in a number of ways, and refer to the choices made about the nature of investment and the exclusion of certain modes of investment that could confer on board members significant political powers.

This paper draws upon a long-term research programme on the governance of financial institutions and especially pension systems. This research has focused upon the political dimensions of fund governance, the various models available that seek to reconcile expertise with representation, best-practice institutional investment decision-making making, and the scope of institutional innovation in a highly uncertain world (see Clark and Urwin 2008a, 2009). ${ }^{3}$ Research is largely case-study based, utilising the skills of field analysis, close-dialogue, and comparative institutional analysis across related jurisdictions. Inevitably, we rely upon exemplars to make our arguments; in this case, the Australian Future Fund is used to illustrate a series of general arguments about the legitimacy of public institutions that have, or seek to sustain, long-term investment mandates. As such, the paper is part of the larger project begun by Monk (2008) on the legitimacy of sovereign wealth funds.

Two caveats ought to be acknowledged from the outset. The first concerns the account of the motives underlying the conception of the Future Fund. There are, no doubt, other ways of writing the story that dispute the significance, for example, of intergenerational equity. Likewise, whereas my story tends to treat the government of the day as a 'responsible' custodian of the future, it is conceivable the government was simply lucky rather than deliberately forward-thinking in its economic policy. Secondly, this paper is about the principles of institutional design in relation to longterm investment. There remain, nevertheless, significant issues to be resolved if the value of the FF is to be realised over the long-term. The paper is less about performance before and after the global financial crisis than it is about the preconditions for effective long-term performance in the face of political temptation (compare Lerner et al. 2008).

\footnotetext{
$3 \%$ See also the website http://www.geog.ox.ac.uk/research/transformations/projects/governance.php for more details on the rationale and publications from the project. Our website www.oxfordswfproject.com is another venue for related research on the nature and performance of sovereign wealth funds.
} 


\section{Temptation, principles and practice}

One of the remarkable features of the past couple of decade or so has been the growth of sovereign wealth funds. ${ }^{4}$ Elsewhere, we account for their growth and the degree to which their significance is an expression of marked global imbalances between the west (favouring consumption over savings) and other resource-rich and trade and exchange-rich countries (favouring saving over consumption) (Clark and Monk 2009). Of course, there are significant differences between the various types of SWFs according to their sources of funds, the extent to which they are representative of long-term structural imbalances, and the degree to which nations that have benefited from trade have captured the generated wealth in SWF institutions (see Eichengreen and Park 2006).

The accumulation of national wealth can be seen as a result of economic development and the incorporation of countries' economies into global commodity chains, trade and exchange. Whether prompted endogenously or through the process of corporate off-shoring and out-sourcing from advanced economies, global economic integration over the past few decades benefited Asian, Latin American, and (to an extent) African countries (see Grossman and Helpman 2005). For some countries, though, there have been significant problems associated with absorbing the wealth generated by trade recognising the small size and immature nature of local market institutions. Concerns about national macroeconomic stability also encouraged the formation of SWFs-in effect, SWFs became a means of keeping assets from overwhelming local markets. It is not surprising, in this context, that off-shore investment in the developed financial markets of the west was a favoured strategy.

In other countries, the burgeoning export of commodities was associated with windfall 'rents' on non-renewable resource endowments rather than being seen as a reward for policies favouring long-term labour productivity, investment, and development. The countries fuelling the growth of China and India, the oil-rich countries of the middle-east, and the staging posts of global trade arguably fall into this category. As noted below, policymakers from these states were very conscious of

4. See http://www.cfr.org/publication/15251/ for the commentary on sovereign wealth funds provided by the US Council on Foreign Relations. 
the contingent nature of these enormous windfalls; they could scarcely believe their luck and were wary about the predictability of such flows of earnings. As the global boom became a bubble, however, nation-states that benefited from burgeoning global trade began to integrate optimistic revenue projections into governments' re-current revenue and expenditure plans. For some, especially those with a legacy of underdevelopment and a political culture of authoritarianism, dependence on such foreign earnings could come at a heavy price (eg. Russia).

For a number of countries, then, policymakers faced a dilemma: they could treat foreign earnings as recurrent revenue but suffer the political consequences should (when) the bubble burst or they could 'park' the assets in special-purpose long-term investment vehicles but suffer the short-term political costs of ignoring the claims of entitlement by organised domestic interests. In modern democracies, subject to the ups and downs of electoral cycles, the short-term political advantages of spending windfall earnings are readily apparent; it is also apparent that the beneficiaries of long-term investment are often not represented in the political process. Put more formally, the democratic political process heavily discounts the future-the discount rate being the product of the length of the political cycle, the degree to which sectional interests underwrite the power of governing parties, and the synchronisation of the political cycle with the economic cycle (Tabellini and Perrson 2000). Managing temptation against long-term commitment is one of the staples of political theory and philosophy and was discussed by the ancient Greeks as the tension between passion and reason (see Slote 1989 for a modern treatment). ${ }^{5}$

It is also apparent that conventional economic theory also discounts the future denying the relevance of sunk costs thereby reinforcing the predilections of politicians in favour of short-termism. In part, the choice of a high discount rate reflects rather simple-minded assumptions about how people properly behave-generalising from everyday behaviour to issues large and small that can be shown to have, nonetheless, long-term consequences for their children and grandchildren. Equally, some analysts have argued that a commitment to the future is too vague and implies an historical

5 . Elsewhere, this issue is discussed in terms of 'weakness-of-will' wherein the problem to be resolved is how and why people may choose a course of action for their long-term benefit only to be swayed at the last minute by some immediate pay-off. See Ainslie (2001) for the seminal treatment and Ainslie (2004) for the debate that this argument has engendered. 
contingency to behaviour that runs against the grain of current methods of economic optimization (as evident in the economic debate over pricing climate change and the proper weight attributed to the future; see Schelling 1996 and Stern 2007). Laslett $(1979,40)$ captured this sentiment in the following statement: "time present is always sovereign, in respect to what is gone by, and of what is still to come."

The degree to which the costs of short-termism loom large depends, in part, on the degree to which political elites expect to be directly accountable when these costs come due. In effect, they must find robust and convincing ways of separating the short-term from the long-term such that the latter does not, under pressure, always collapse into the former. At one level, this problem can be seen as an issue of rhetoric-that is, an issue of convincing political constituencies that the favoured solution is plausible and beneficial to future generations (as suggested by Wolfe 2008). For some analysts, rhetoric is naturally associated with hypocrisy in that any such solution involves in some form or another duplicity or worse. At another level, though, scepticism is the natural antidote to political hypocrisy-politicians must mobilize constituents' interests in ways that evidently govern their self-interests while holding out a solution to acknowledged temptation on both sides of the equation (Runciman 2008).

Noting temptation, Nozick $(1993,10)$ pointed to the advantages of a principledapproach to political decision-making: "principles constitute a form of binding" ourselves to the future and are especially effective when chosen principles are characterised by "generality, no proper names, and no positional predicates" (pages 56). A freely-chosen principle which transcends the specific claims of an individual or a group as well as the exigencies of the moment will have the legitimacy to "constrain the influence of undesired or irrelevant factors" (page 7) in favour of a commonly accepted goal or objective. If long-term investment is legitimated with reference to a principle or over-riding goal that transcends the claims of special interests, such a principle may effectively "constrain" the temptation of giving-in to claims for current consumption. For Nozick, this logic was not only a normative proposition about the proper role of institutions it also reflected the customary practice of many people selfconscious about the (self-defeating) costs of temptation (Schick 1997). 
Of course, a principled approach to governing temptation can be accused of being overly abstract and effectively 'empty' when faced with the real-world of reciprocal relationships (Blackburn 1998; ch. 4). Nozick observed that a principled-approach to governing temptation depends upon four strategies or practices. In the first instance, the choice of an over-arching principle must be justifiable. That is, it must be explained and debated so that whatever residual disagreement which remains is effectively neutralised (if not denied) when implemented. In the second instance, the chosen over-arching principle must be recognised as such, becoming a reference point for public discourse thereby being accepted as a reason to 'trump' the claims of special interests. Third, policymakers must be shown to have made a commitment to the principle thereby translating often distrusted political rhetoric into accepted policy practice. And fourth, there should be clear instances of adherence to the principle such that the public come to expect it to govern behaviour (their own included) when dealing with the relevant issues. ${ }^{6}$

In what follows, it is suggested that the political sponsors of the Future Fund invoked a principle-based approach to the establishment of the fund. They did so cognisant of latent political support amongst core supporters of the governing Liberal Party for managing the looming costs of an ageing society while recognising the pressures within the governing coalition and the incentives faced by the Labor opposition to distribute the windfalls due to trade and privatisation for short-term political gain. The government did so in a strategic manner.

But by adopting a principle-based approach, it gave life to Scanlon's (1998, 191) argument to the effect that the 'social contract' that binds people together now and in the future is based on "principles which no one could reasonably reject". This strategy was conceived in the context of pressing macroeconomic issues and was implemented through a fund governance regime that promises to hold the government of the day accountable to the principled-approach to policy making.

\footnotetext{
$\%$. This last point is important in the sense that it suggests that governments can, and should, promote shared expectations of proper behaviour such that, over time, those expectations become integral to common understandings of what is right and proper. See George (1993, 44-45) on the distinction between regulating behaviour through the rule of law and inculcating a "good moral ecology (that) benefits people by encouraging and supporting their efforts to be good".
} 


\section{Economic growth and macroeconomic management}

Whereas global integration through trade and exchange was an integral part of the post-1945 consensus in favour of liberalisation and market development, it is arguable that geopolitics also played a crucial role in prompting the opening of western markets to exports from less developed economies and states previously excluded by reason of their alliances with the former Soviet Union and China. The consensus in favour of peace through trade and development was of great benefit to may countries seeking to export to western markets. Perhaps less expected was the boom and then bubble over the past decade in the prices of some countries' non-renewable resources. Peter Costello (2008), the Treasurer of the Commonwealth of Australia over the period 1996-2007, noted the parlous budgetary position of the government when he assumed office, a shrinking tax base against planned expenditures, and the political difficulties involved in carrying-through management of the economy in the face of global economic and financial instability (see Figure 1 and the accumulation of government debt through to 1997$)^{7}$

\section{[INSERT FIGURE 1 ABOUT HERE]}

Against expectations, however, the Australian government managed to return seven budget surpluses through to 2004 (see also Figure 1). Whereas austerity was Costello's initial budget strategy, by 2001 tax revenue had begun to grow faster than expected on the back of the export of raw commodities such as coal and iron ore to north-east Asia. So significant was the inflow of tax revenue that the Australian government was able to retire most of its inherited debt by 2004 . In fact, the government decided not to retire all its debt only because of concerns over the consequences of such a move for the efficient pricing of domestic financial securities. Instead of paying down all debt, the government decided to collect its growing receipts into an arms-length investment fund-the Future Fund-for the stated purpose of funding the costs of unfunded defined benefit pension liabilities associated with federal government civil servants. Even with the closure of the scheme to new participants in 2006, it was estimated that the costs of such pensions will reach AUS $\$ 140$ billion by 2040 .

\footnotetext{
7 . The nature of the data presented and the sources of the data are presented in the Appendix.
} 
The governing Liberal Party was dependent upon on a coalition with a small party based upon rural interests for its majority in the House of Representatives and the passage of legislation through the Senate. As well, because of competition between the Treasurer and the Prime Minister for power within the governing coalition, and deepening poverty in pockets of major cities, 'responsible' national financial management was contested at each phase in the transition from budget 'crisis' to establishing the Future Fund. Not withstanding the windfall in tax revenue, the government was constrained in spending its 'surplus' revenue for two reasons. When elected, the Liberal government devolved responsibility for interest-rate setting to the Reserve Bank of Australia (anticipating the UK Labor government's 1997 action). The Reserve Bank proved to be a strong player in macroeconomic policy, willing to increase and decrease interest rates at any stage in the electoral cycle. This 'external' discipline empowered the Treasurer in dealing with colleagues' claims for increased government spending given the ever-present threat of inflation (see Figure 2).

\section{[INSERT FIGURE 2 ABOUT HERE]}

Also important was the fact that the Australian economy is rather small relative to the growth in export revenue; this is not an argument about economic immaturity but one about the inability of the economy to absorb the volume of exogenously generated wealth. As unemployment dipped to historical lows, as real income began to grow, and as property prices took on expectations of growth well-beyond acknowledged shortfalls in supply in regional markets government saving through budget surplus and the pay-down of debt were the obvious options for reigning-in burgeoning domestic demand (see Figure 3). The increasing value of the Australian dollar against the US dollar and, to some extent, European currencies did little to dampen domestic demand. In this sense, the creation of a sovereign wealth fund to store 'excess' national wealth may have became government policy for macroeconomic reasons rather than for achieving the stated purpose of funding long-term pension liabilities.

[INSERT FIGURE 3 ABOUT HERE] 
Here, though, a further issue loomed large. Whereas many countries that created SWFs over the past twenty years did so in the hope that such an institution would also stimulate the development of their financial systems, Australia has a highly developed financial market with large financial institutions and deep liquidity provided, in part, by the compulsory second-pillar defined contribution pension system. From a modest beginning in the mid-1980s, the growth in superannuation contributions, the returns generated by improving markets over the late 1990s through to the global credit crisis and the concentration of assets in a relatively small number of large cost-conscious providers saw financial assets grow from 30 percent of GDP in 1980 to 130 percent of GDP in 2007. Further, anticipating developments in other western countries, reforms to federal financial regulation through the 1990s combined with a robust national competition regime were conceived so as to encourage innovation across the financial sector while protecting against market volatility. ${ }^{8}$ The FF was not, however, designed to be a lender of last-resort should the national financial system be adversely affected by global financial events.

In fact, the Future Fund was formed in the context of a sophisticated and growing domestic financial system with unrestricted access to global financial markets (as evident in the growth of global infrastructure investment groups). With an initial endowment provided by government, combining tax receipts with its share of the outstanding stock of the privatized telco (Telstra), it could claim the interest of leading investment houses without dominating the domestic financial system. Further, as noted below, its long-term mandate provided a rationale for investment management rather different than that apparent in the hurly-burly of the short-term competition for assets amongst the large pension providers. With his decision to locate the fund in Melbourne rather than Sydney (the largest Australian city and most significant financial centre), the Treasurer exercised his residual power over his Sydney-based rival — the Prime Minister — to reinforce the place of his 'home' city in the global economy.

\footnotetext{
8 . The Wallis inquiry into financial regulation was established by Treasurer Costello when the Liberal party assumed office in 2006. The report of the inquiry sought to modernise regulation, recognising the significance of new forms of communication, the growing role of intermediation, and the growth of different types of financial institutions. See Commonwealth of Australia (1997). It took seriously the functional model of finance developed by Merton $(1993,1995)$ and his colleagues. See also Merton and Bodie (2005).
} 


\section{Intergenerational equity}

By this account, the Future Fund was the product of national macroeconomic management, fortuitous global circumstances, and the strategic management of political interests that would have otherwise spent the largesse of economic growth in the highly contested short-term Australian political cycle. As such, the notional object of the Future Fund-federal government unfunded defined benefit pension liabilities-was a debt of convenience rather than the rationale for establishing the Fund. In less fortuitous macroeconomic circumstances, it is doubtful whether the government would have been willing or able to sequester such financial resources. As the gathering global financial crisis has come to dominate the Australian economy and government finances, the Future Fund has also become the object of claims made on behalf of current taxpayers to discount the costs of the recession.

It is arguable that the legitimacy of the Future Fund was underwritten by a more substantial claim than macroeconomic imperatives and expediency. In interview, the previous Treasurer Peter Costello made an explicit link between the Liberal government's early commitment to intergenerational accounting and the full-funding of long-term federal superannuation obligations, arguing that the expected value of those obligations was such that they would be an unjustified burden on the welfare of future generations. In the first Intergenerational Report (2002), produced as a Budget Paper for 2002-2003 and presented in Parliament by the Treasurer, the government emphasised the long-term prospects for Australia in the context of an ageing society, declining fertility, and the sensitivity of immigration to economic conditions. In doing so, the government matched concerns expressed by the World Bank (1994) and amplified by other multilateral institutions over the 1990s that current government spending and the expected value of future entitlements may not be economically sustainable.

The implications of this proposition for government finances has been used to scrutinise the current funding and long-term sustainability of countries' social security and health care systems (see Leibfritz et al. 1995; Gruber and Wise 1999). It became an essential reference point for the reform of many countries' pensions systems, and was especially important in continental Europe (see Clark 2003). In Australia's case, however, pension reform had taken place in the 1980s with the adoption of a 
compulsory second pillar pension system and a compulsory national health care insurance scheme. Nonetheless, three related implications for government finances were drawn from the 2002 Intergenerational Report. First, the management and paying-down of current debt was an essential ingredient in planning for the future; second, Australia's international competitiveness depended on maintaining its reputation as a "lower taxing and spending country", and; third, promoting long-term economic growth was crucial if the expected costs associated with an ageing population were to be met without impoverishing future generations.

The logic of intergenerational accounting is explained in Auerbach, Kotlikoff and Leibfritz (1999), in their early work separately and together (see Auerbach et al. 1994; Kotlikoff 1992), and is applied to Australia by Ablett (1999). In summary terms, intergenerational accounting applied to government expenditure can be thought to be based upon four principles: transparency, comprehensiveness, discipline, and a distinction between current spending and investment. Transparency refers to itemising and accounting for the cost of current and future commitments; comprehesiveness refers to a full-accounting of all obligations whether 'on-the-books' or not; discipline refers to the political temptations of engaging in spending policies that carry moral hazard; and, the distinction between spending and investment refers to allocating the burden of paying for different types of public goods where the costs and benefits of investment may be distributed far into the future. In their international comparison of generational balances, Kotlikoff and Leibfritz (1999, 85 and 99-100) concluded that Australia like a number of other countries faced a "substantial imbalance" favouring current generations over future generations.

Foreshadowing legislation establishing the Future Fund, the Treasurer in answer to a question in Parliament observed that the Future Fund was "designed to fund Australia to meet the costs of the ageing of the population" and "in particular, unfunded superannuation liabilities". In doing so, Costello invoked a principled-approach to policy making augmented by his hard-earned reputation for fiscal responsibility over the past decade. Though silent on the specific constituency to which his argument was addressed, it appears he appealed to core supporters of the Liberal party specifically those retired and the baby-boom generation who were the beneficiaries of the past decade of rising incomes and house prices. Although the Labor opposition 
noted that this initiative was accompanied elsewhere in the budget with superannuation reforms and tax concessions aimed at those constituents, the opposition focused on the logic of the initiative rather than antagonise voters that it would have to win-over at the pending next election.

To emphasize the significance of the initiative, Costello contended that the “Commonwealth's unfunded superannuation liabilities (were) at the moment AUS\$90 billion" and were "expected to grow by 2020 to AUS $\$ 140$ billion" (Hansard 6 December 2005, page 3). These figures were disputed in both the House of Representatives and the Senate. Tanner, the Labor Party spokesman on finance, argued in the House that the percentage share of government outlays due to superannuation was just a "couple of points" and would not likely grow to more than 3.5 percent (ㅂansard 7 February 2006, page 42). In the Senate it was claimed, in fact, that by 2041 these liabilities would halve in value against expected GDP (Hansard 7 February 2006, page E18). For Tanner, unfunded obligations could be paid for out of future economic growth encouraged by a Future Fund focused upon "investment in infrastructure" (ㅂansard 7 February 2006, page 48). ${ }^{9}$

At issue for Tanner and the Labor opposition (which won the late 2007 federal election) was whether the establishment of an investment fund would be an effective way of realising the future value of what they deemed to be windfall gains from the "spectacular boost in commodity prices driven by demand in China" (Hansard 7 February 2006, page 48). There were other options, including passing-on the initial allocation of AUS\$18 billion to a combined federal government employees' pension fund thereby using the administrative and investment resources of the existing defined contribution scheme to manage the DB liability. The government, however, sought to distinguish between individual account-based pension fund investment and the liabilities associated with defined benefit schemes arguing that the governance of these schemes was not compatible. ${ }^{10}$ It was also contended that the Future Fund

\footnotetext{
$\%$. This remains a significant point of contention, with some commentators arguing that infrastructure investment that boosts labor productivity has a more beneficial effect for the whole economy than a finance sector that invests assets through capital markets. There is considerable academic debate about this issue; see King and Levine (1993a, 1993b).

$10 \%$ In theory, it is clear that institutions are better governed if they have unambiguous mandates or objective functions. This point is developed in Clark and Urwin (2008a) with respect to best practice
} 
would not perform any better than the long-term government bond rate in which case it would be better to use the assets to sustain the infrastructure necessary to realise a higher overall rate of economic growth. The government suggested that the Labor Party's claim for infrastructure was "code" for pork-barrel politics.

The possibility that Future Fund assets could be subverted by special interests was raised on both sides of the House. For this reason, the government's enabling legislation excluded the Fund from owning directly real assets like property and infrastructure. Nonetheless, the Labor opposition thought that even this provision could be "very easily circumvented" using "modern financial instruments" and suggested that the coalition partners, the National Party, would find ways to raid the fund "for political purposes" (ㅂansard 7 February 2006, page 47). ${ }^{11}$ Both sides of the House agreed that the governance of the fund was to be a crucial bulwark against political temptation and the means by which the Fund's assets would be properly managed on behalf of future generations of Australians. Time and again, the principle was invoked to frame of the terms of the political debate.

\section{Best-practice governance}

Throughout the passage of the Future Fund legislation, consideration was given to the proper governance of the fund. The government referred to expert advice on this matter received from a number of sources including the international investment and pension fund consulting firm Watson Wyatt. This company has led industry consulting on the issue, with recent published research on best practice investment management (see Clark and Urwin 2008a, 2008b). Research has established a 12point criterion for evaluating standards of fund governance, including a set of three issues sensitive to both the size of funds (asset value) and the goals and objectives of the sponsoring institutions. It should be noted, moreover, that while these standards were framed with reference to pension funds, endowments and related beneficial

pension fund governance and serves to underline the relevance of the argument that defined benefit and defined contribution pension plans serve very different interests over distinctly different time horizons.

11 . When the government came to sell the third tranche of Telsra shares, the National Party negotiated the establishment of another endowment fund whose income would be invested in rural telecommunications infrastructure. That fund was abolished with the support of the Liberal Party when the Labor opposition assumed government. I am indebted to Nick Howarth in pointing this out. 
institutions, the criteria established were intended to apply to a wide variety of investment institutions including sovereign wealth funds.

The design of an institution for a new function is a rare event. More often than not, institutions once created claim new responsibilities carrying with them the compromises and conditions at the time of establishment amplified or dampened by experience (see, more generally, Roe 2006). In this case, the government took the opportunity to follow industry best-practice without the obligation to match or copy established pension funds. The resulting governance framework and management structure has been assessed and scored by a number of commentators. For example, Truman (2008) gave the fund a score of 26.5 out of a possible 33, suggesting that its governance regime was, perhaps, less effective than a number of other similar institutions (such as the Canadian CPPib and CalPERS) but far more effective than other non-pension related SWFs especially those from Asia and the Middle East. Not withstanding the recent establishment of the fund, Truman indicated that there were some shortfalls in governance in the reporting of investment activities. ${ }^{12}$

Scoring is a useful means of institutional comparison. But to the extent that scoring seeks to be all-encompassing in terms of the criteria used to judge form and functions, scoring tends to weigh equally more and less important criteria. As well, in using a common format for scoring each criterion the distinctive characteristics of different funds may be ignored not withstanding the apparent commonalities shared by institutions. More problematic, however, is the assumption that scoring is meaningful without a deep understanding of each and every fund. Using the best practice framework developed in Clark and Urwin (2008a) as a reference point, we also scored the FF and gave it a score of 12.9 out of 15 , a score that placed it amongst the very best institutions that we know and have evaluated. ${ }^{13}$ Using this framework, we

\footnotetext{
$12 \%$ In fact, close scrutiny of Truman's scoring suggests that the zero values attributed to four elements of transparency and accountability were mistaken given the recent establishment of the fund and the constitution of its long-term mandate. If that is the case, the FF would have scored the same as the CPPib and the New Zealand Superannuation Fund.

13\% The Clark-Urwin governance scoring system was conceived to be a diagnostic tool for evaluating the form and functions of investment institutions including SWFs, pension funds, and endowments. It has developed from our work on global best practice, and the nature of institutional innovation in the context of the global financial crisis (see Clark and Urwin 2008a, 2009).
} 
emphasise certain aspects of the Future Fund that are innovative with reference to comparator institutions.

In the best-practice framework, elements of 'good' governance were arranged under three headings: institutional coherence, referring to the framing of investment decision-making; people, referring to those responsible and involved in decisionmaking, and; process, referring to the mechanisms by which investment is managed and implemented. Elsewhere, this framework is developed by focusing upon the resources of governance and the role of leadership is rationalising the management of investment under risk and uncertainty (Clark and Urwin 2008b). For present purposes, we emphasize certain aspects of the three elements of good governance especially the clarity of the fund's mission statement (institutional coherence), the size and composition of the fund board (people), the role of board members in relation to the real-time execution of investment management, and the choice made to manage investment through a network of external providers rather than manage assets internally or through a mix of internal and external management (process).

The mandate of the fund was set in the legislation (February 2006) and is found in detail in the first Ministerial investment mandate or directions issued in May 2006. As set out in Section 15 of the Act, the "main" objective of the fund is to "enhance the ability of the Commonwealth to discharge unfunded superannuation liabilities" subject to Section 18 wherein (1) "the responsible Ministers may give the Board written directions about the performance of its (the fund's) investment functions" and (2) in doing so, "responsible Ministers must have regard to: (a) maximising the return earned on the Fund over the long term, consistent with international best practice for institutional investment; and (b) such other matters as the responsible Ministers consider relevant." In the Investment Mandate, the benchmark rate of return was set at CPI plus 4.5 to 5.5 percent subject to a long term asset allocation strategy and an acceptable level of risk "measured in terms such as the probability of losses in a particular year." A series of conditions were set, including ensuring that the fund did not adversely affect the efficient functioning of Australia financial markets.

In these ways, the mandate of the fund was set in principle and in practice. The objective was unequivocal and the investment process was given a behavioural logic 
(maximising returns), a strategic template (long term asset allocation and risk management), and a return target (range of returns). As such, the investment mandate matched similar frameworks found in other countries amongst pension-related investment institutions (see, for example, CPPib and MassPRIM; Clark 2008). The mandate also gave clear guidance as regards avoiding, as much as possible, adverse outcomes that may have political costs for the government sponsor. For example, the Board was required to limit yearly reported losses, minimise the effects of its actions on Australian stock markets, restrict holdings of domestic companies' stock such that it does not trigger Australian takeover rules and regulations while also limiting its holding of foreign-listed firms' common stock to no more than 20 percent.

The enabling legislation also established the Future Fund Management Agency, an entity operating within the ambit of the federal government and "responsible for assisting and advising the Board." This agency is, effectively, the operational arm of the Board subject to the direction of the Chair of the Board as Head of the agency. The enabling legislation simply set-out the functions of the agency such that Section 75 detailed 7 such functions while allowing for other functions incidental to the performance of those enumerated functions.

In terms of its operational role, the Board published in November 2008 a statement of objectives as regards the investment approach of the Future Fund Management Agency. Here, five points were made. First, that the Agency would emphasize longrun, total portfolio risks rather than asset-specific risks (assuming the long-run is 10 years). Second, the Agency acknowledged the limits of relying upon historical data on risk and return, especially over the long-term. Third, given the long-term, the Agency would ensure portfolio diversification in relation to key macroeconomic indicators such as inflation, growth, and market liquidity. Fourth, rather than rely upon asset classes, the Agency would use strategies such that asset classes would be the components of long-term investment. And fifth, the fund would take advantage of its long-term time horizon in being the 'investor of choice' for third-parties. To realise these objectives, the Board decided not to become an institution with its own investment capacity (unlike the CPPib) but rely upon the market for investment management. 


\section{Board structure and responsibility}

Perhaps the most important innovation in the governance of the Future Fund came with the size and composition of the Board and the government's conceptualization of its responsibilities: board members were deemed "guardians" rather than trustees. In countries with a strong English common law heritage members of pension fund boards are trustees in that they act as fiduciaries with respect to the interests of beneficiaries. In many jurisdictions, pension fund boards combine representation with expertise-board members are selected on the basis of the stakeholder group they represent and the expertise they may bring to board deliberations (Clark 2007). In defined benefit plans, this dual role or function can produce quite large boards with rather heterogeneous skills and expertise. In some jurisdictions, the premium on representation in multiemployer public sector plans can result in boards with as many as 15-21 appointed members. Not surprisingly, there can be significant coordination problems with such boards especially where large numbers encourage the shirking of responsibilities and grandstanding in deliberations (Clark and Urwin 2008c).

In theory, at least, the optimal number of members of boards that rely upon collegial or collective decision-making is in the order of 5-7 with an independent chair (see Clark and Urwin 2008b on the ecology of pension fund decision-making and Sunstein 2005 on the related evidence gleaned from psychology and organisational theory). As for the Future Fund, the board has six members with an independent chair appointed by the government rather than elected from within the board. The chair was appointed in the first instance for 5 years, while 3 board members were selected for an initial 3 year term and the other 3 for an initial 5 year term. It is anticipated that, if desired by the board members, the group of 3 appointed for 3 years will be reappointed. Ideally, the term of appointment will be 5 years with renewal on the basis of a performance review.

Research on the competence and consistency of pension fund decision-making suggests that effective investment decision-making under risk and uncertainty depends on board members' skills and education (Clark et al. 2007). It would appear that experience without formal training, and general knowledge of the field without task-specific experience, means that many boards are unable to deal with the contingency of financial markets (see Wagner 2002 on the nature of expertise and 
Clark 2008 on the distinctive characteristics of financial markets and the implications for board member expertise). In statute (Section 38), to be eligible for appointment as a Future Fund board member such persons must have "(a) substantial experience or expertise; and (b) professional credibility and significant standing in at least one of the following fields: (c) investing in financial assets; (d) the management of investment in financial assets; (e) corporate governance". In many jurisdictions, there are no such "qualifications" to be a trustee. Instead, trustees are simply required to act in a prudent manner consistent with commonsense. ${ }^{14}$

In interview, Peter Costello observed that, all things being equal, board members could come from a variety of states and meet community expectations as regards diversity. Crucial, though, was the expectation that board members would have the presence of mind and independence of thought to stand against the government of the day to protect the integrity of the Future Fund. As acknowledged on both sides of the debate in parliament, governments will be tempted to influence investment decisionmaking and siphon-off assets for their immediate political advantage. Being appointed a "Guardian" is to stand guard against short-term political interests, a mandate for behaviour that references community norms and expectations and that goes well beyond the requirements of simply being a 'professional' (see Clark 2008 on the significance of this type of norm for governing institutions).

In a number of ways, the government sought to protect board members from immediate political affect, and sustain their legitimacy. So, for example, the term of appointment of 5 years with the prospect of renewal was expected to severer the link with the short-term political cycle. The required expertise of board members and the presumption in favour of their independence from political commitment was deemed to match the successful 'reform' of the Reserve Bank of Australia initiated by Peter Costello in his first year of appointment as federal Treasurer (emulated by the UK Labor government with respect to the independence of the Bank of England). The small size of the board, the premium on expertise and experience, and the personal

\footnotetext{
$14 \%$ Notice that board members are also required to "discharge his or her duties with the degree of care and diligence that a reasonable person would exercise". See Section 56 of the Act. Elsewhere in the Act (Section 24), the board is required to formulate "written policies" pertaining to the investment strategy of the fund is a manner consistent with "international best practice for institutional investment."
} 
accountability of board members for investment strategy may enable the development of a collective sense of guardianship often times missing in large pension fund boards wherein the competing claims of various represented interests can lead to consensual decision-making such that dissent is registered by silence or the search for the lowest common denominator (Clark and Urwin 2008c).

Crucially, the Future Fund is not a pension fund in two respects. If nominally established to meet the long-term superannuation liabilities of the closed Commonwealth defined benefit plan, participants in the plan have no claim on the assets of the Future Fund. Their pension entitlements remain a claim on the plan sponsor (the Commonwealth government) and its future tax receipts. The plan is 'unfunded' and is administered as a pay-as-you-go system with the prospect of 'funding' from 2020. As such, the pension entitlements of participants are not reliant upon the performance of the Future Fund. One implication of this arrangement is that risk management is not a function of short-term and long-term asset-liability matching. Risk management is important, but not in the same sense as existing pension plans (Bauer et al. 2006). In this respect, the Future Fund is an investment platform much like the Canadian CPPib shorn of responsibility for administering the underlying pension fund and focused exclusively on maximising the rate of return subject to an appropriate level of risk. It has certain advantages over the CPPib including its explicit long-term mandate.

As important is the fact that the Future Fund exists and will continue to exist at the will of the government of the day and ultimately parliament. Time and again in debate it was observed that "a parliament can not commit a future parliament legislatively" (see, for example, the 7 February 2006 Senate hearings and the exchange between Senator Stephens and an expert witness; Hansard page E16-17). In essence, other than the contractual commitments made by the fund to investment providers, a future parliament could alter the form and functions of the fund and indeed close the fund and claim the assets. By this logic, the responsibility of guardians is a responsibility to future generations of taxpayers to ensure that that the best intentions of the government in establishing the Fund are honoured not withstanding the legitimacy of future claims that might be made on those assets for other reasons and other uses. Guardians may act like trustees in that they act as 
fiduciaries. Nonetheless, their commitment is to the future welfare of Australians not the entitlements of plan participants.

\section{Long-term investment}

Given the significance of intergenerational equity for the establishment of the Future Fund, it is clear that the fund will be held to account for its contribution to the welfare of future generations of Australians. This is a rather abstract time horizon although the period through to 2040 (the date where the payment of superannuation benefits will likely to conclude) could be thought to encompass two or perhaps three future generations: those born but not yet taxpayers, those to be born through to 2030, and those to be born after 2030. To the extent that the Future Fund enables future governments to release scarce resources for investment in the development of Australia, thereby doing more than simply paying the retirement benefits of retirees, it is also arguable that investment in the fabric of economic development will benefit generations born beyond 2030 .

More specifically, the long-term was formally identified in the government's commentary on the enabling legislation as 2020 (the likely date when the balance of income and benefit payments is likely to switch to net outflow) and 2040. The latter date has a degree of certainty because the plan is closed to new members; while benefits may accrue, mortality tables can give reasonable though not entirely dependable estimates about the expected longevity of plan participants. While obviously important, neither the claims of future generations nor the plan 'trigger' dates are operational definitions of long-term investment. In this case, the board considering the various options and chose 10 years as the effective long-term time horizon for planning investment risk-adjusted rates of return. Given the short time horizons of Australian super funds, being largely preoccupied with quarter-to-quarter returns, it is arguable that the Future Fund has no obvious Australian peers. Its peers are large pension-related SWFs from other countries.

The board also decided to pursue an absolute return strategy subject to an explicit risk-budget rather than use industry or institutional benchmarks. This issue was debated at length at the board-benchmarks are standard practice in the investment management industry (Clark 2000; Shleifer 1988). However, it has been observed by 
industry commentators that benchmarking can encourage backsliding on any commitment to invest over the long-term (Shiller 2002). In any event, since the Future Fund relies upon the financial market for investment management, to use yearly or even tri-annual benchmarks would likely reinforce the short-termism and predilections for churning portfolios observed in the industry. Here, the fund riskbudget is the governing instrument and is set in relation to long-term economic movements in the desired balance between asset classes. Note, the board is sensitive to short-term volatility in fund performance because of the questions that might be prompted about its underlying competence and success.

Whether the long-term is defined by reference to generations, the onset of expected liabilities or operational targets, ten years out is a highly unusual time horizon. It is a time horizon sensitive to structural change, technological innovation, and demographic transformation. As such, the implication is plain: if acted upon, investment is about placing bets on the map of global climate change, the winners at the frontier of technology and innovation, and the place of Australia in relation to the global economy. At the same time, the long-term is also sensitive to the pace of global economic integration and stability of financial markets. In this respect, a tenyear time horizon could encompass two or three economic cycles, a boom and bust, and a global crisis. A ten-year time horizon is also sensitive to the global coordination of economic regulation as well as the degree to which one kind of regulatory regime for a block of countries may, or may not be, a 'winning' model over other kinds of regulatory regimes and their participating. La Porta et al.'s (1998) maps of finance may be a template for fund investment.

Whereas the implied scope of a rolling ten-year investment programme is structural and global, it is also entirely plausible that since the fund is one of just a few institutions with such scope of activity it has, as a consequence, some responsibility for contributing to the realisation of long-term economic and environmental goals. More to the point, in the second Intergenerational Report (2007) the government sought to establish a connection between the apparent goal of fiscal sustainability introduced in the first Intergenerational Report and the "wellbeing of successive generations" which "requires sustainable economic, social and environmental conditions" (page 1). If the second reports reads as an election manifesto promoted 
by the Treasurer seeking to supplant the incumbent Prime Minister and win the election on his own account, the extended definition of intergenerational equity is unmistakeable. In doing so, the overarching principle legitimating the Future Fund was extended to include long-term social and environmental conditions-points of reference not included in the more limited initial financial conception of intergenerational equity.

This suggests, however, a rather broader set of responsibilities for the Future Fund than that set in statute and by the Investment Mandate. Whereas it is clear that the long-term investment horizon of the fund will involve taking bets on the map of climate change, the second Intergenerational Report suggests that the fund has, as well, an obligation to ensure that its investments are 'sustainable' in the sense that either these commitments do not harm the prospects of future generations (Norton 1989) or contribute to the cultural and ecological heritage that we pass from one generation to the next (Weiss 1984). If challenging in terms of its scope and implied obligations, long term investment involves much more than exploiting the map of opportunities. Indeed, Weiss $(1984,581)$ suggested that we (the current generation) are the trustees for future generations and as such "have a fiduciary obligation to conserve this heritage for future generations". Few public institutions have both the mandate and the obligation to do so as the Future Fund. ${ }^{15}$

It may be argued, of course, that the purpose of the fund was limited to realising future superannuation commitments. But, as noted above, the government invoked the principle of intergenerational equity to transcend expectations that the fund was just another pension fund in disguise. In any event, recognising the rolling 10 year investment time horizon, there can be little doubt that investing in structural change may mean, as well, investing in technological innovation conceived to 'solve' or at least benefit from attempts to mitigate the effects of climate change. By this logic, such an investment strategy would be consistent with the past government's preferred definition of intergenerational equity. But it may have significant consequences for the Future Fund's investment strategy if the anticipated frontier of innovation results

15\% I am grateful for Claire Woods for making this point and identifying the relevant literature. 
in the long-term discounting of the value of the inherited fossil fuel economy (the basis of much of Australia's foreign earnings and the endowment of the Future Fund).

\section{Conclusions}

In many respects, the Australian FF is the latest institution in a line of similar institutions conceived and designed by western governments to manage, politically and economically, the windfall benefits of commodity endowments and trade. Compared to the Alberta Heritage Fund, the Alaska fund, and the Norwegian Petroleum Fund (renamed recently as the Pension Fund), the government sponsor of the FF tackled directly some of the political issues that have bedevilled the effective operation of other, older institutions. So, for example, using a principle-based approach enables the government to focus on the long-term holding at bay the claims of organised groups for a share in current investment earnings. Similarly, barring the direct ownership of real assets strengthens the hand of the FF's board and management in resisting political claims that the institution should invest in public and private projects deemed important for national development. ${ }^{16}$ One way or another, its best-practice governance is an expression of lessons learnt from other jurisdictions.

It has been argued by some observers that the Australian Future Fund is just a pension fund. This interpretation is encouraged by the legislative goals and objectives of the fund, namely the funding of the unfunded defined benefit pension liabilities of federal government employees. Reference to 2020 as the expected date when the payments of benefits will first outweigh the inflow of contributions and reference to 2040 as the likely date when the government's commitments will be exhausted were clearly important for the government when setting the investment mandate for the fund. Nonetheless, the underlying principle legitimating the establishment of the fund was intergenerational equity not the government's obligations to its employees. It was argued here that invoking this principle served two purposes: to sustain the government's intended meaning of the long-term and, thereby, to provide a principled

\footnotetext{
16\% Another interpretation of this provision (suggested by Eric Knight) is that it means that the fund would not be a direct competitor to private infrastructure investors such as Macquarie Bank. Rather it will rely upon this growing sector of the Australian finance industry.
} 
defence of the integrity of the fund in the face of likely political interests in suborning the fund's asset for other purposes.

The principle of intergeneration equity stands against another basic principle underpinning Westminster democracies: that parliament can not bind the hands of future parliaments. While contracts written in the past must be honoured by present governments (or compensation paid to affected parties), parliaments have the right to re-write and discard past legislation in favour of the policies of the day. In this respect, the Future Fund is more vulnerable than a pension fund to the political winds of change. In many jurisdictions, pension plan participants have, at least, a legal claim on the assets of their pension plan; in effect, their promised benefits or their account balances are 'property' protected by statute and common law. In this case, government employees do not have a claim on the assets of the Future Fund. This fact is apparent in the choice made by the government to label board members 'guardians' rather than 'trustees'. By our interpretation, the government meant to invest the role of its guardians with a higher purpose than that attributed to pension fund trustees.

In these ways, the government sought to tame politics and govern temptation. It did so mindful of the short-term political benefits of spending its windfall from the remarkable burst in revenue associated with the boom in non-renewable resource exports to China. It did so with the grudging support of the opposition Labor party which became the governing party in 2008. Peter Costello was able to enlist their support, in part because of the appeal of the notion of intergenerational equity and in part because of their fascination with the apparent political machinations within the governing parties over the competing claims for spending the money. We argued, though, that the principle of intergenerational equity carries with it a larger scope than the funding of future pension obligations. That is, the principle can be interpreted more broadly that the simple statements of commitment made in the enabling legislation. This is apparent in the re-written conception of intergenerational equity underpinning the 2007 report. There, fiscal sustainability is joined by social and environmental sustainability providing a broad rationale for investment. 
Whether this principled approach to the establishment of the Future Fund will be an effective governing device remains to be seen. Care must be taken not to idealise either the design of the institution or its capacity to realise its founders' intentions. The global credit crisis which came almost immediately after the establishment of the fund and the first steps in developing its investment strategy will be a test of the current government's commitment to the institution and the degree to which a principle adopted in certain circumstances can hold back or should hold back changing economic imperatives. In crisis, governments have claimed-back committed public and private resources, witness the Argentine government's expropriation of the assets of private pension plans. 


\section{References}

Ablett, J. 1999. Generational accounting in Australia. An international comparison of generational accounts. In Generational Accounting Around the World edited by A. J. Auerbach, L. J. Kotlikoff and W. Leibfritz. Chicago: University of Chicago Press, pp. $141-159$

Ainslie, G. 2001. Breakdown of Will. Cambridge: Cambridge University Press

Ainslie, G. 2004. Précis of Breakdown of Will. Behavioral and Brain Sciences 28:635-50

Auerbach, A. J. 1994. Generational accounting. Journal of Economic Perspectives 8(1)73-94

Auerbach, A. J. and Kotlikoff, L. J. 1999. The methodology of generational accounting. In Generational Accounting Around the World edited by A. J. Auerbach, L. J. Kotlikoff and W. Leibfritz. Chicago: University of Chicago Press, pp. 31-42

Bauer, R., Hoevenaars, R. and Steenkamp, T. 2006. Asset liability management. In The Oxford Handbook of Pension and Retirement Income edited by G. L. Clark, A. Munnell, and M. Orszag. Oxford: Oxford University Press, pp. 441-455

Blackburn, S. 1998. Ruling Passions. Oxford: Oxford University Press

Blundell-Wignall, A., Hu, Y, W., and Yermo, J. 2008. Sovereign wealth funds and pension fund issues. Paris: OECD

Clark, G. L. 2000. Pension Fund Capitalism. Oxford: Oxford University Press

Clark, G. L. 2003. European Pensions \& Global Finance. Oxford: Oxford University Press

Clark, G. L. 2007. Expertise and representation in financial institutions: UK legislation on pension fund governance and US regulation of the mutual fund industry. $21^{\text {st }}$ Century Society: Journal of the Academy of Social Sciences 2:1-23

Clark, G. L. 2008. Governing finance: global imperatives and the challenge of reconciling community representation with expertise. Economic Geography 84:281302

Clark, G. L. 2009. Risk management and institutional investors. In Managing Financial Risks: From the Global to the Local edited by G. L. Clark, A. Dixon and A. Monk. Oxford: Oxford University Press (forthcoming)

Clark, G. L., Caerlewy-Smith, E., and Marshall, J. 2007. The consistency of UK pension fund trustee decision-making. Journal of Pension Economics and Finance 6:67-86 
Clark, G. L. and Monk, A. H. B. 2009. The financial crisis: the rise and demise of SWFs. Working Paper. Oxford: Oxford University Centre for the Environment

Clark, G. L. and Urwin, R. 2008a Best-practice investment management. Journal of Asset Management 9(1):2-21

Clark, G. L. and Urwin, R. 2008b. A resource-based approach to collective decisionmaking under risk and uncertainty: implications for pension fund governance. WPG08-08. Oxford: Oxford University Centre for the Environment

Clark, G. L. and Urwin, R. 2008c Making pension boards work: the critical role of leadership. Rotman Journal of International Pension Management 1:38-45

Clark, G. L. and Urwin, R. 2009. Innovative models of UK pension fund governance. Working Paper. Oxford: Oxford University Centre for the Environment

Commonwealth of Australia. 1997. Financial System Inquiry: Final Report. Canberra ACT: Australian Government

Commonwealth of Australia. 2002. Intergenerational Report 2002-2003. Budget Paper 5. Canberra ACT: Australian Government

Commonwealth of Australia. 2007. Intergenerational Report 2007. Canberra ACT: Australian Government

Costello, P. with P. Coleman. 2008. The Costello Memoirs. Melbourne: Melbourne University Press

Eichengreen, B. and Park, Y. C. 2006. Global imbalances: implications for emerging Asia and Latin America. Mimeo. Berkeley: Department of Economics, University of California

Future Fund. 2008a. Annual Report 2007/08. Canberra ACT: Australian Government Future Fund. 2008b. Statement of Investment Policies. Melbourne: Australian Government

George, R. P. 1993. Making Men Moral: Civil Liberties and Public Morality. Oxford: Oxford University Press

Grossman, G. M. and Helpman, E. 2005. Outsourcing in a global economy. Review of Economic Studies 72:135-59

Gruber, J. and Wise, D. (Eds.) 1999. Social Security and Retirement around the World. Chicago: University of Chicago Press

Kahneman, D. and Tversky, A. 1979. Prospect theory: an analysis of decisions under risk. Econometrica 47:263-91 
King, R. and Levine, R. 1993a. Finance and growth: Schumpeter might be right. Quarterly Journal of Economics 108:717-37

King, R. and Levine, R. 1993b. Finance, entrepreneurship, and growth: theory and evidence. Journal of Monetary Economics 32:513-43

Kotlikoff, L. J. 1992. Generational Accounting. New York: Free Press

Kotlikoff, L. J. and Leibfritz, W. 1999. An international comparison of generational accounts. In Generational Accounting Around the World edited by A. J. Auerbach, L. J. Kotlikoff and W. Leibfritz. Chicago: University of Chicago Press, pp. 73-101

La Porta, R., Lopez-de-Silanes, F. Shleifer, A. and Vishny, R. 1997. Legal determinants of external finance. Journal of Finance 52:1131-50

Laslett, P. 1979. The conversation between generations. In Philosophy, Politics \& Society Fifth Series, edited by P. Laslett and J. Fishkin. New Haven: Yale University Press, pp. 36-56

Leibfritz, W., Roseveare, D., Fore, D., and Wurzel, E. 1995. Age populations, pension systems, and government budgets: how do they affect savings? Economics Working Paper 156. Paris: OECD

Lerner, J., Schoar, A. and Wang, J. 2008. Secrets of the academy: the drivers of university endowment success. Available at http://ssrn.com/abstract=1271374

Merton, R. 1993. Operation and regulation in financial intermediation: a functional perspective. In Operation and Regulation of Financial Markets edited by P. Englund. Stockholm: Ekonomiska Rắdet, pp. 17-67

Merton, R. 1995. Financial innovation and the management and regulation of financial institutions. Journal of Banking and Finance 19:461-81

Merton, R. and Bodie, Z. 2005. The design of financial systems: towards a synthesis of function and structure. Journal of Investment Management 3:1-23

Monk, A. 2008. Recasting the sovereign wealth fund debate: trust, legitimacy, and governance. Available at http://ssrn.com/abstract=1134862

Norton, B. G. 1989. Intergenerational equity and environmental decisions: a model using Rawls' veil of ignorance. Ecological Economics 1:137-59

Nozick, R. 1993. The Nature of Rationality. Princeton: Princeton University Press

Puranam, P. and Vanneste, B. S. 2009. Trust and governance: untangling a tangled web. Academy of Management Review 34:11-31

Roe, M. J. 2006. Legal origins, politics, and stock markets. Harvard Law Review $120: 460-527$ 
Runciman, D. 2008. Political Hypocrisy: The Mask of Power, from Hobbes to Orwell and Beyond. Princeton: Princeton University Press

Scanlon, T. M. 1998. What We Owe to Each Other. Cambridge MA: Harvard University Press

Schelling, T. C. 1996. Global decisions for the very long term: intergenerational and international discounting. In Wise Choices: Decisions, Games and Negotiations edited by R. Zeckhauser, R. Keeney and J. Sebenius. Boston: Harvard Business School Press, pp. 152-66

Schick, F. 1997. Making Choices: A Recasting of Decision Theory. Cambridge: Cambridge University Press

Sebenius, J. K. 1996. Sequencing to build coalitions: with whom should I talk first? In Wise Choices: Decisions, Games and Negotiations edited by R. Zeckhauser, R. Keeney and J. K. Sebenius. Boston: Harvard Business School Press, pp. 324-48

Shiller, R. 2002. Bubbles, human judgement, and expert opinion. Financial Analysts Journal 58(3):18-26

Shleifer, A. 1985. A theory of yardstick competition. Rand Journal of Economics $16: 319-27$

Slote, M. 1989. Beyond Optimizing: A Study of Rational Choice. Cambridge MA: Harvard University Press

Stern, N. 2007. The Economics of Climate Change: The Stern Review. Cambridge: Cambridge University Press

Sunstein, C. 2005. Group judgements: statistical means, deliberation, and information markets. New York Law Review 80:962-1049

Tabellini, G. and Persson, T. 2000. Political Economics. Cambridge MA: MIT Press

Truman, E. 2008. A blueprint for sovereign wealth fund best practices. Policy Brief PB08-3. Washington DC: Peterson Institute for International Economics

Weiss, E. B. 1984. The planetary trust: conservation and intergenerational equity. Ecology Law Quarterly 11:495-581

Wolfe, M. 2008. The shadows of future generations. Duke Law Journal 57:1897-932

World Bank. 1994. Averting the Old Age Crisis. Washington DC 


\section{Appendix. Data sources}

Figure 1. Income and Unemployment (Australia 1990 - 2008): "Real net national disposable income per capita: Volume measures". Source: Australian Bureau of Statistics (http://www.abs.gov.au/), Australian System of National Accounts, 2007-08 (cat no. 5204.0), Table 1. Key National Accounts Aggregates, Series ID A2420637R. Australian Dollars. Real incomes payable and receivable are calculated by dividing the nominal income flows by the implicit price deflator for gross national expenditure. In the derivation of the aggregate, all of the adjustments are made using the chain volume aggregation method used to derive all of the ABS chain volume estimates.

"Unemployment rate; Persons". Source: Australian Bureau of Statistics (http://www.abs.gov.au/), Labour Force, Australia, Spreadsheets, Dec 2008 (cat no. 6202.0.55.001), Table 03. Labour force status by Sex, Series ID A163165V Converted from monthly to annual in percentage terms. Unemployment rate; For any group, the number of unemployed persons expressed as a percentage of the labour force in the same group.

Figure 2. CPI and Housing Investment (Australia 1990 - 2007): "Consumer Price Index, All groups". Source: Australian Bureau of Statistics (http://www.abs.gov.au/), Australian Economic Indicators, Jan 2009 (cat no. 1350.0), Chapter 5 — Prices, Table 1 Table 5.1-Consumer Price Index, ANNUAL-By group.

"Private housing investment". Source: Australian Bureau of Statistics (http://www.abs.gov.au/), Australian Economic Indicators, Jan 2009 (cat no. 1350.0), Chapter 5 - Prices, Table 12 Table 5.7-Selected Housing Price and related Indexes, ANNUAL-Original.

\section{Figure 3. Australian Trade and Government Accounts (1990 - 2007):}

"Trade on goods and services". Source: Australian Bureau of Statistics (http://www.abs.gov.au/), International Trade in Goods and Services, Australia, Nov 2008 (cat no. 5368.0), Table 2. GOODS AND SERVICES, Summary: Original, Current prices, Series ID A592264J. Australian Dollars (millions). Converted from monthly to annual (data for 2008 includes Jan-Nov).

"Federal Government cash balance". Source: Final Budget Outcome 2007-08, circulated by the Honourable Wayne Swan MP Treasurer of the Commonwealth of Australia and the Honourable Lindsay Tanner MP Minister for Finance and Deregulation for the information of Honourable members, September 2008, Appendix B: Historical Fiscal Data, page 88, posted at: http://www.budget.gov.au/. Australian Dollars (millions). Underlying cash balance is equal to receipts less payments less Future Fund earnings. 


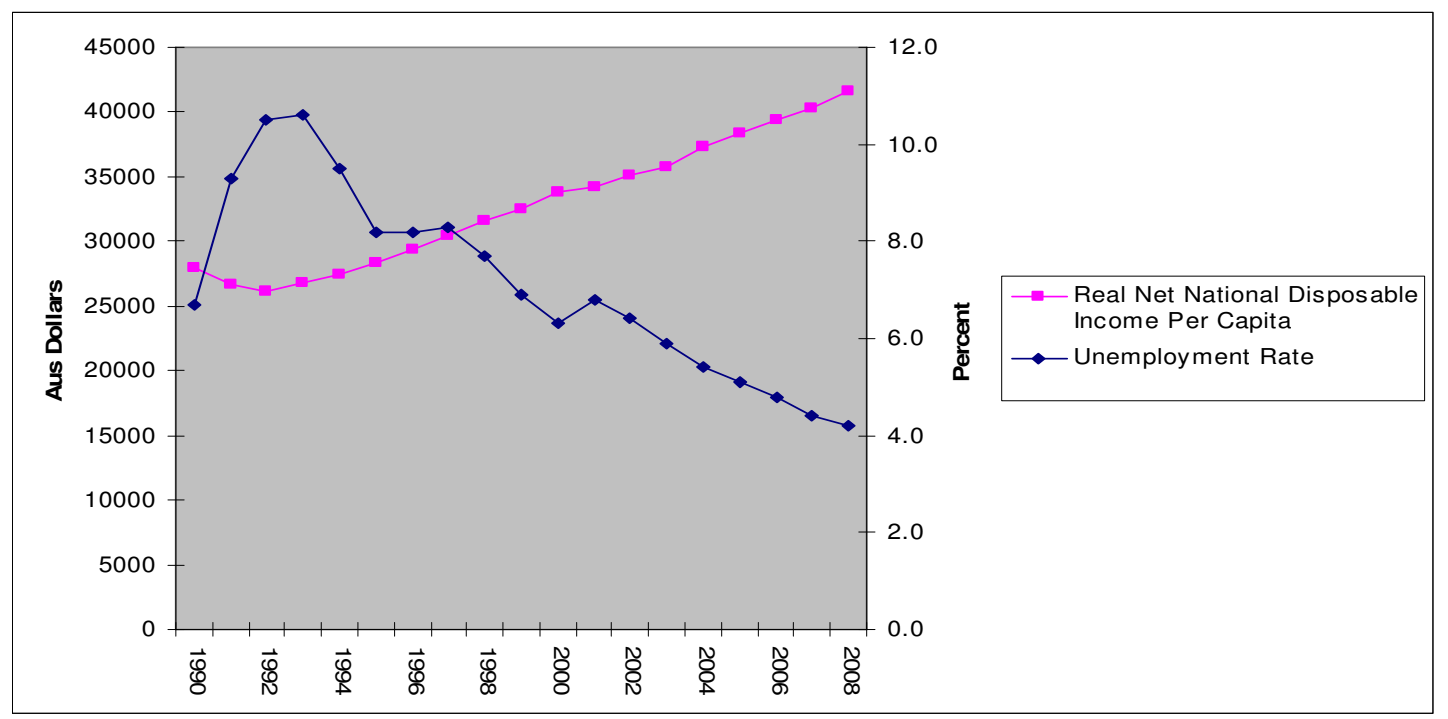

Figure 1. Income and Unemployment (Australia 1990 - 2008)

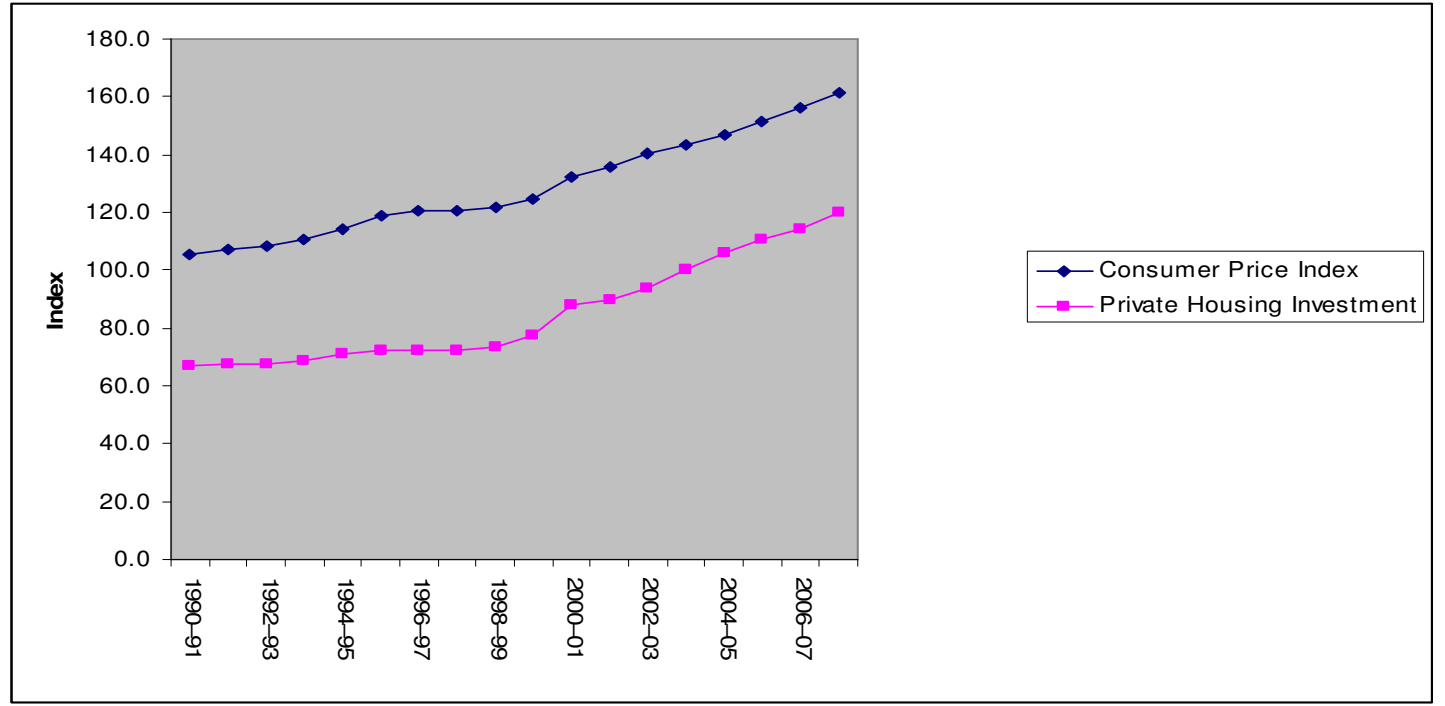

Figure 2. CPI and Housing Investment (Australia 1990 - 2007)

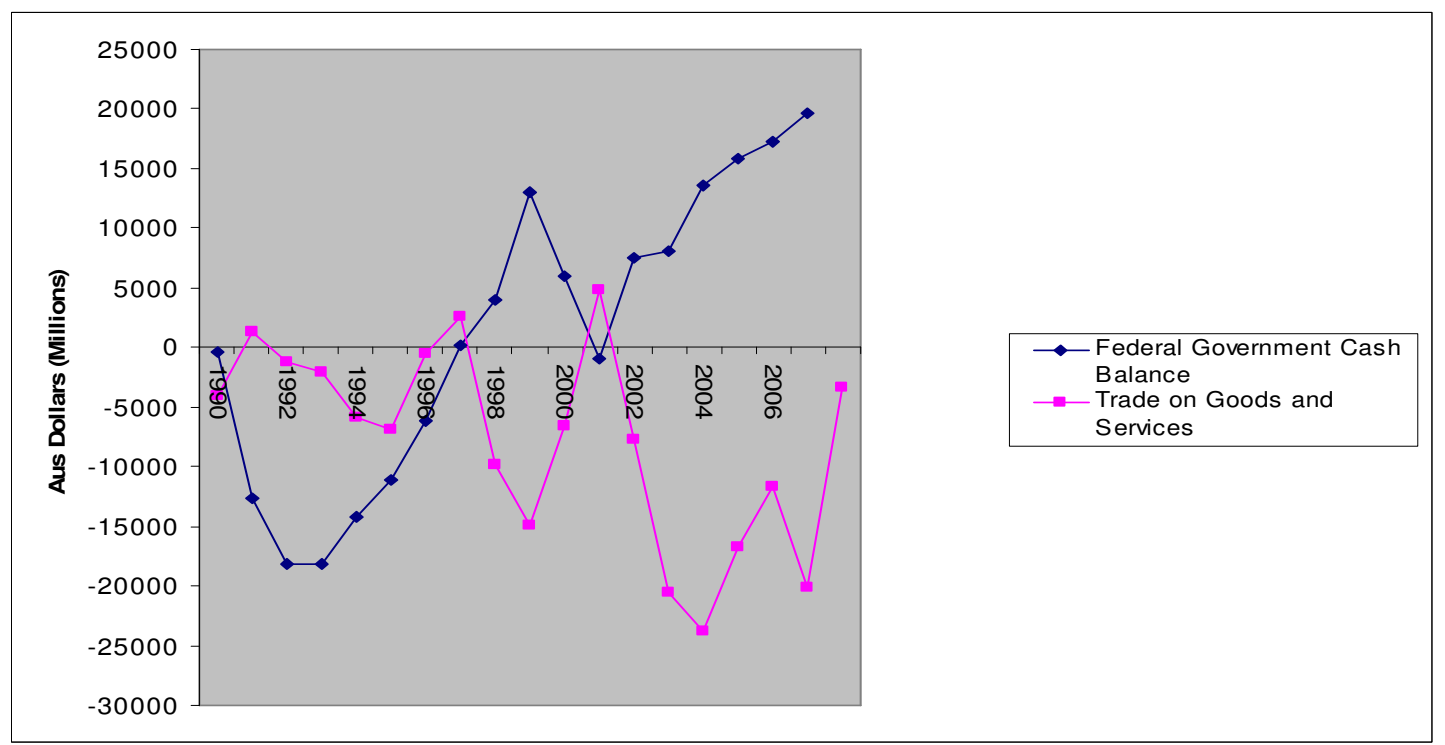

Figure 3. Australian Trade and Government Accounts (1990 - 2007) 